\title{
MANAGEMENT OF RADIOLOGICAL CAPACITY OF SURFACE WATER ECOSYSTEMS, WHICH INCLUDES TECHNOLOGICAL RESERVOIRS OF NPPS
}

\author{
Grygorieva L. I., Makarova O. V.
}

\section{INTRODUCTION}

The world has long realized the inevitability of the end of the fossil fuel era, the use of which also significantly harms the environment. In anticipation of the scarcity of energy resources, the developed countries of Europe have decided to focus on nuclear and renewable energy as the most affordable clean technologies.

The domestic nuclear industry is represented by four stations: Zaporizhzhya, Rivne, South-Ukrainian and Khmelnitsky, which have 15 units. Ukrainian NPPs produce more than $50 \%$ of the country's electricity daily, and in some days last year the NPP's share in the energy balance even exceeded $65 \%$.

At the same time, as evidenced by numerous radioecological studies around NPPs, the activity of the latter affects the radiation status of the adjacent territories. Due to the influx of radionuclides into the environment in the process of nuclear energy production, the studies of radionuclide migration in aquatic ecosystems remain extremely relevant. Particularly noteworthy are studies on the behavior of radionuclides in freshwater ecosystems, which are hydrodynamically linked to coolant rates and other NPPs.

Materials from radiological studies conducted by various scientific institutions in the south of Ukraine show that there are many anthropogenic and natural radiation factors in the region that affect the environment and human health.

Today, there are a number of works on radioecology of aquatic ecosystems, including aquatic ecosystems in southern Ukraine. Much less work is devoted to the radioecology of freshwater ecosystems, which include the technological reservoirs of NPPs in the region of the South-Ukrainian Nuclear Power Plant (SUNPP).

It is known that aquatic biota and bottom sediments of reservoirs can significantly affect the radiation status of reservoirs. Knowing the basic patterns of radionuclide distribution in the components of these ecosystems, one can reasonably predict the radioactive contamination of the aquatic ecosystem and, if necessary, use a set of countermeasures to reduce the existing level of pollution. 
The paper uses materials of long-term radioecological studies to evaluate the migration of radiocesium in the freshwater ecosystem of the Southern Bug, which includes the technological reservoirs of SUNPP.

\section{Methodology for assessing the functioning and viability of a freshwater ecosystem}

Radionuclides may be present in water as a constituent of various chemical compounds, in water-soluble form or in suspension. Water in reservoirs plays the role of a link in the chain of radionuclide migration to its soil and biological components. It is known that sediments have a high sorption capacity for different radionuclides: the concentration equilibrium between water and sediments is set at a factor of $10^{2}-10^{3}$.

This high absorption capacity of the bottom sediments is due to the high amount of organic matter contained in them and being in a highly dispersed colloidal state. The concentration equilibrium between water and sediment may shift. One of the most important factors affecting the ability of bottom sediments to absorb is the acid reaction $(\mathrm{pH})$ of water. By reducing the $\mathrm{pH}$ of the reservoir in the acidic side, the yield of absorbed radionuclides can reach $50 \%$ or more. Therefore, for the sediments to deposit and retain radionuclides, the $\mathrm{pH}$ of the water should be 7-9.

The bulk of living matter in the natural reservoir is plankton and microbenthos. The reproduction time of these organisms ranges from tens of minutes to tens of hours, so the productivity of the microorganisms is much higher than other representatives of the biota. Aquatic vegetation, which is of great importance in the energy balance of aquatic ecosystems, also constitutes a significant amount of reservoir biomass. It forms the basis of nutrition for many aquatic animals and plays a significant role in the creation of detritus in the reservoir.

Active sorption of radionuclides by water vegetation leads first to their removal from water, and after the vegetation dies - to replenishment of the activity of bottom sediments ${ }^{1}$.

Due to the rapid change in the cycles of generations of aquatic organisms, the biomass of the reservoir plays a significant role in the transport of radionuclides from water to the bottom sediments. The total radioactivity transported by biomass during the season from the water to the sediments may be $10^{2}-10^{3}$ times the biota activity. In this way, the function of purification of water from the radionuclide reservoir by the biota of the reservoir and the function of transporting the radionuclide from the water into the bottom sediments by the biota. An important activity of biota in the reservoir is the regulation of the active reaction of water $(\mathrm{pH})$. In water bodies with significantly developed biomass, the active water response is

${ }^{1}$ Кутлахмедов Ю., Корогодін В., Кольтовер В. Основи радіоекології. Київ : Вища школа, 2003. 
neutral or slightly alkaline. An actively functioning biota contributes to the formation of sediments and increases the fixation of sorbed radionuclides in them. Schematically the role of biota in the freshwater reservoir is presented in Figure 1.

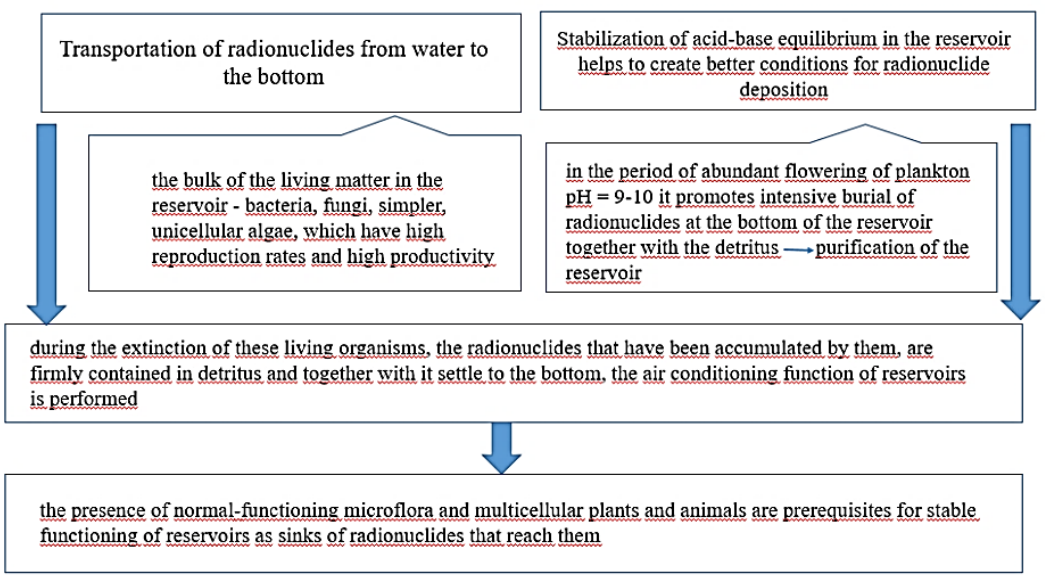

\section{Fig. 1. The role of biota in the freshwater ecosystem}

One of the more accessible approaches for assessing the radiation status of a reservoir is the method of estimating its water intensity by constructing a chamber model.

The total activity of radionuclides $\mathrm{A}(\mathrm{Bk})$ in the reservoir under the condition of equilibrium between water and sludge is determined by the formula:

$$
A=C \cdot S(H+k h),
$$

where $\mathrm{C}$ is the bulk activity of radionuclides in water, $\mathrm{Bq} / 1 ; \mathrm{S}$ - surface area (bottom) of the reservoir, $\mathrm{m}^{2} ; \mathrm{H}$ - water depth, $\mathrm{m}$; $\mathrm{k}$ is the radionuclide accumulation factor of the upper layer of bottom sediments; $h$ is the thickness of the sediment layer, $\mathrm{m}$.

The part of the activity of radionuclides contained in the bottom sediments - the factor of the intensity of the bottom sediments is determined by the formula:

$$
F_{\text {дон }}=\frac{k h}{H+k h},
$$


with a high content of biota in the reservoir, up to $90 \%$ of the total activity of radionuclides that have reached the reservoir enters the biomass of the biota. The reservoir radioactivity factor with biotic component will be determined by the formula:

$$
F_{\text {biota }}=\frac{P K H}{H+k h+P_{6} K_{6} H},
$$

where $\mathrm{Pb}$ is the amount of biota per unit volume of water, $\mathrm{kg} / \mathrm{m}^{3} ; \mathrm{KB}$ is the average rate of accumulation of radionuclides by biota.

In technological reservoirs - ponds of NPP coolers - because of the high temperature throughout the year, and therefore the availability of sufficient food for the fish that live in these reservoirs, the herd of fish reaches tens of thousands of tons. Therefore, the radioecological assessment of the NPP technological reservoirs should take into account the fish capacity factor as components of the ecosystem ${ }^{2}$.

The radioactivity factor of the fishery component of the freshwater ecosystem can be defined as follows:

$$
F_{\text {fish }}=\frac{P_{p} K_{p} H}{H+k h+P_{\sigma} K_{\sigma} H+P_{p} K_{p} H},
$$

where Pp is the number of fish per unit volume of water, $\mathrm{kg} / \mathrm{m}^{3} ; \mathrm{Kp}$ is the average rate of radionuclide accumulation by fish.

Radioactivity factors are a function of variables $(\mathrm{k}, \mathrm{h}, \mathrm{P}, \mathrm{H}, \mathrm{K}, \mathrm{P} 2, \mathrm{~K} 2)$ that depend on biological (species of biota, its number and diversity, stage of development and vegetation period, sorption properties), chemical (water $\mathrm{pH}$, mineral composition), physical (water temperature, transparency, oxygen content, etc.), hydrological (fluctuations in volume, movement of water layers, presence of flow, evaporation and replenishment of water, precipitation) and environmental (inflow of harmful substances, use of reservoirs for economic needs $t$ etc.) factors.

\section{Radio-ecological assessment of the state of the freshwater ecosystem of the southern bug river in the area of the south Ukrainian (south) NPP due to its radiocapacity}

The ecosystem of the Southern Bug River is characterized by the presence of different ways of receiving artificial radionuclides, including radio cesium: flushing of radionuclides from the contaminated Chernobyl discharges of river catchment areas; the cooler rate of the Southeast NPP and others (Fig. 2).

\footnotetext{
${ }^{2}$ Радіоекологія. Камерні моделі / Ю. Кутлахмедов та ін. 2013.
} 


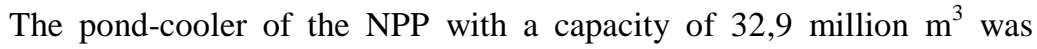
formed in the Tashlyk beam on the left bank of the Southern Bug River (near the village of Konstantinovka). Its length is $10 \mathrm{~km}$, width from $1 \mathrm{~km}$ in the lower part to 100 meters at the top, average depth of $10 \mathrm{~m}-0,25 \mathrm{~m} / \mathrm{s}$ at the bottom. The nature of water circulation in a reservoir is turbulent, water exchange occurs between all layers of the reservoir.

Liquid discharges of Southeast NPPs after pre-treatment are mixed with economic and fecal discharges of NPPs and the city of Yuzhnoukrainsk and through treatment facilities, which include other technological reservoirs ponds, bio-sedimentation tanks, since 1993 are discharged into the pondcooler, which is permanently discharged to the Southern Bug. Purging water. The purge rate of the cooler is carried out in the Southern Bug at a speed of $2 \mathrm{~m}^{3} / \mathrm{s}$, with a total annual volume of 63 million $\mathrm{m}^{3} /$ year. At the same time from the river in the same mode is replenished water losses in the pondcooler.

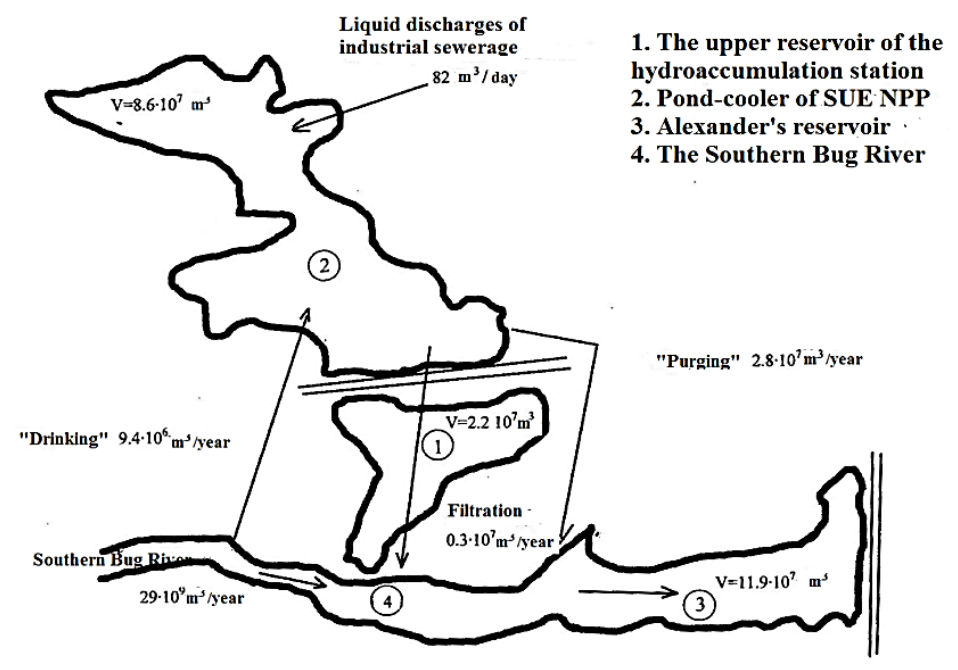

\section{Fig. 2. Scheme of hydrological connection of the reservoirs of the Southeast NPP area}

Due to the fact that various physicochemical, hydrological and other processes occurring in aquatic systems significantly change the ways of radionuclide migration in the aquatic environment, which, in turn, significantly affects the quantitative distribution of radioactivity between different food chains (drinking, fish others), the study of the behavior of one 
of the biologically significant radionuclides - radiocesium - is relevant and timely.

We carried out radio-ecological studies of water samples, which were taken from the technological reservoir - cooler pond of the SUNPP, and from the Southern Bug River (Fig. 3):

- 1 point - Southern Bug River, pumping station of the cooler of the South-East NPP;

- 2 point - cooler pond near the dam emergency gateway;

- 3 point - the Southern Bug River at the discharge point of the purge waters of the cooler of the Southeast NPP;

- 4 point - Southern Bug River, $500 \mathrm{~m}$ below point 3 (control line);

- 5 point - Southern Bug River, $7 \mathrm{~km}$ below point 3.

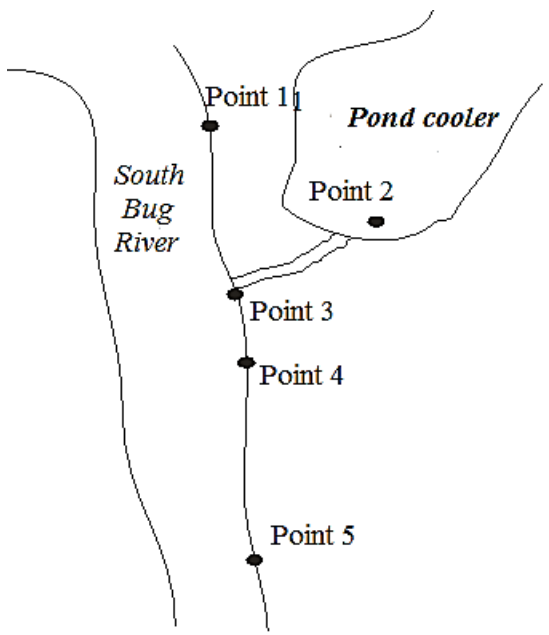

Fig. 3. Monitoring control points

Samples were collected at each observation site on a monthly basis during 1999-2019. Sampling and preparation were carried out using official (standard) methods. ${ }^{137} \mathrm{Cs}$ activity measurements were performed by gammaray spectrometry on an SBS-50 m unit with the DGCK-175V3 detector system with minimally detected radiocesium activity in an unconcentrated sample of 2,5 Bq/l. The measurement error did not exceed $10-15 \%$.

At the beginning of the work, an assessment of the physicochemical state of the NPP cooler was performed. Water pond-cooler has a low alkaline reaction and average oxidation with high mineralization (up to $1146 \mathrm{mg} / \mathrm{l}$ ). Water mineralization is affected by drains from the surrounding area. Nitrate content is $2,9 \mathrm{mg} / 1$, phosphate $-1,7 \mathrm{mg} / 1$, iron $-0,1 \mathrm{mg} / 1$. Hydrothermal 
studies of the reservoir show that basically all areas of the reservoir are involved in the cooling process. The average monthly temperature of the upper reservoir reaches $35-39{ }^{\circ} \mathrm{C}$.

The results of determining the specific activity of ${ }^{137} \mathrm{Cs}$ at each observation point during 1999-2019 indicated that the specific activity of ${ }^{137} \mathrm{Cs}$ fluctuated over a wide range $(0,0117)$ in the water of the Southern Bug River at the location of the pumping station of the cooler at the Southeast NPP ((point 1) $\div 0,035 \mathrm{~Bq} / 1)$ at an average annual value of $0,0175 \pm 0,0021$ $\mathrm{Bq} / 1$ during this period. The results of the statistical processing of these studies indicated the lack of stability of the level of radio cesium activity on the site of the Southern Bug River above the location of the Southeast NPP. Thus, in 1999, in 2003 and 2004, the coefficients of variation of radiocesium activity indicators were more than $30 \%$, in 2000-2002 these values were at the level of 14-26\%. The maximum rate of variation of data during the year was recorded in $1999(3,8)$ and the minimum $(1,9)$ in 2003-2004.

An analysis of the dynamics of radiocesium activity in river water at this point of observation (Fig. 4) showed that at an average annual activity value of ${ }^{137} \mathrm{Cs} 0,0164 \pm 0,0065 \mathrm{~Bq} / 1$, the activity of ${ }^{137} \mathrm{Cs}$ increased from time to time. The maximum increase reached 2 times the natural level. The most frequent increases of 10-20\% occurred in the spring (March - May) and autumn (October - November).

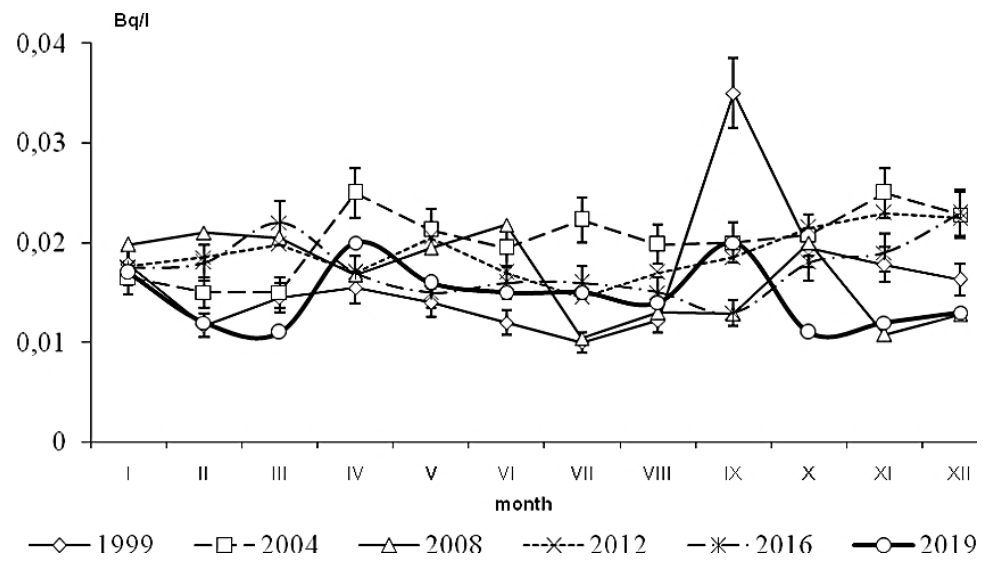

Fig. 4. Dynamics during the year of ${ }^{137} \mathrm{Cs}$ specific activity in the water of the Southern Bug River near the pumping station of the NPP cooler feeder (for the period 1999-2019)

The average annual activity of radiocesium in the water of the pondcooler was $0,025 \pm 0,004 \mathrm{~Bq} / 1$. Scattering of data during each year of 
observations ranged from 6 to 26\%, and in the last three years (2014-2019) this fluctuation was much lower than in previous years.

Comparison of the dynamics of ${ }^{137} \mathrm{Cs}$ specific activity in the water of the cooler pond during each year of observations (Fig. 5) with the corresponding dynamics for river water in the area of the pumping station of the cooler of the YuU NPP (Fig. 1) shows the analogy between these dynamics. Thus, the maximum values of radio cesium activity in the cooler pond were in March - April or October, that is, in the spring and autumn seasons.

Results of determination of radio cesium activity in the water of the Southern Bug River on the river section from the place of discharge of "purge" waters from the pond-cooler to the village. Buzke (7 km below) (Fig. 5-8) showed significant fluctuations in the content of radiocesium at this site. Decrease in the activity of radiocesium in river water with increasing distance from the discharge point into the river of "purging" waters of the cooler of the Southeast NPP: from 0,0197-0,0034 Bq / 1 at point 3 to $0,0154-0,0033$ at the point 5 .

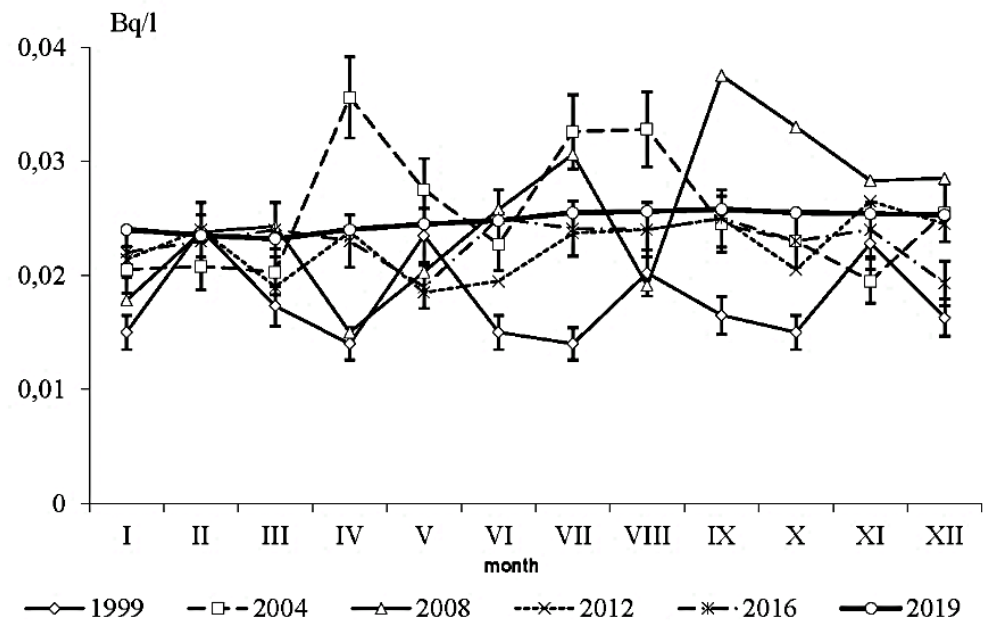

Fig. 5. Dynamics during the year of specific activity of ${ }^{137} \mathrm{Cs}$ in the water of the cooler of the Southeast NPP (for the period 1999-2019) 


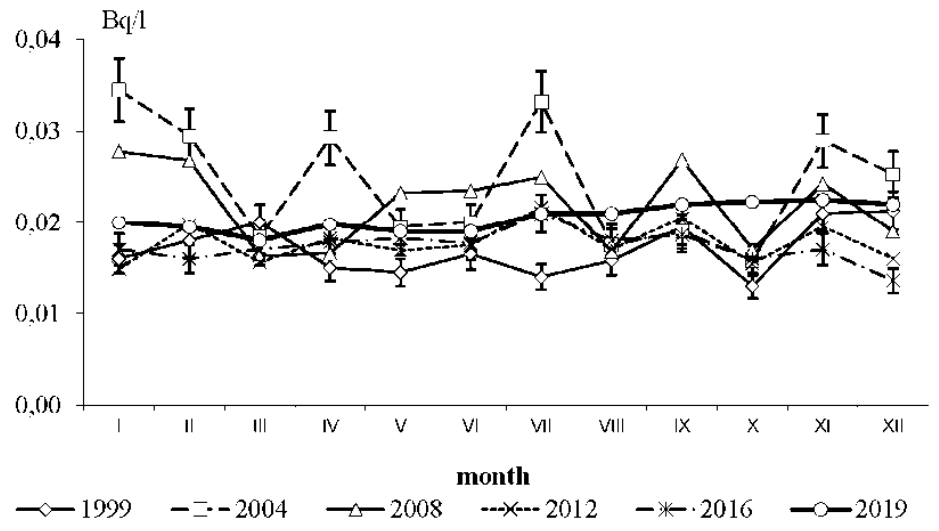

Fig. 6. Dynamics during the year of specific activity of ${ }^{137} \mathrm{Cs}$ in the water of the Southern Bug River in the area of discharge of waste waters (for the period 1999-2019)

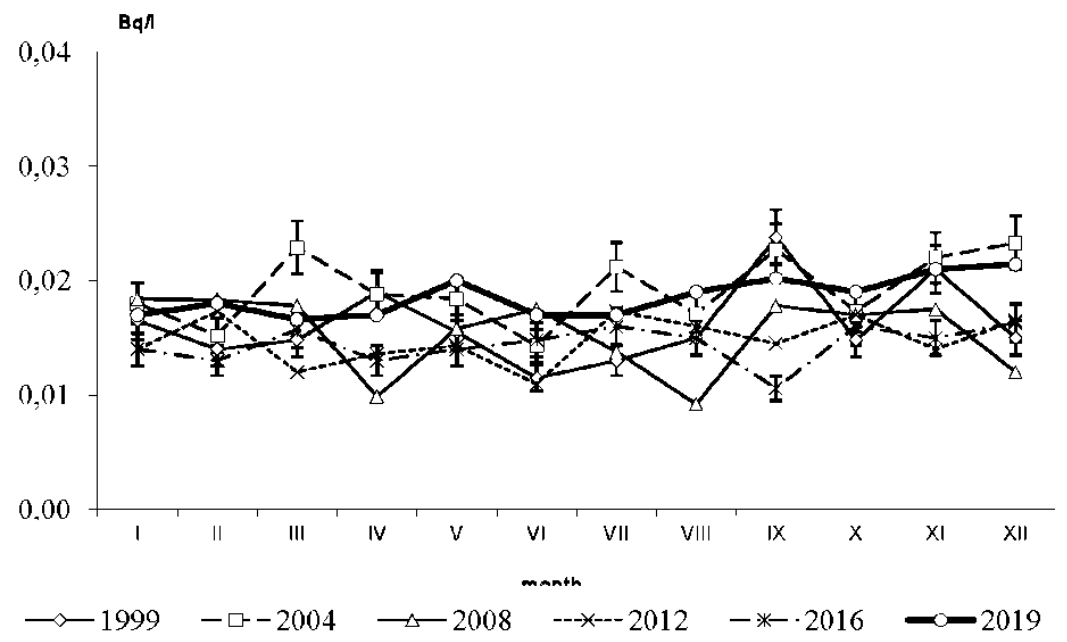

Fig. 7. Dynamics during the year of specific activity of ${ }^{137} \mathrm{Cs}$ in the water of the Southern Bug River in the area of the control establishment (500 $\mathrm{m}$ below the discharge of waste water) (for the period 1999-2019) 


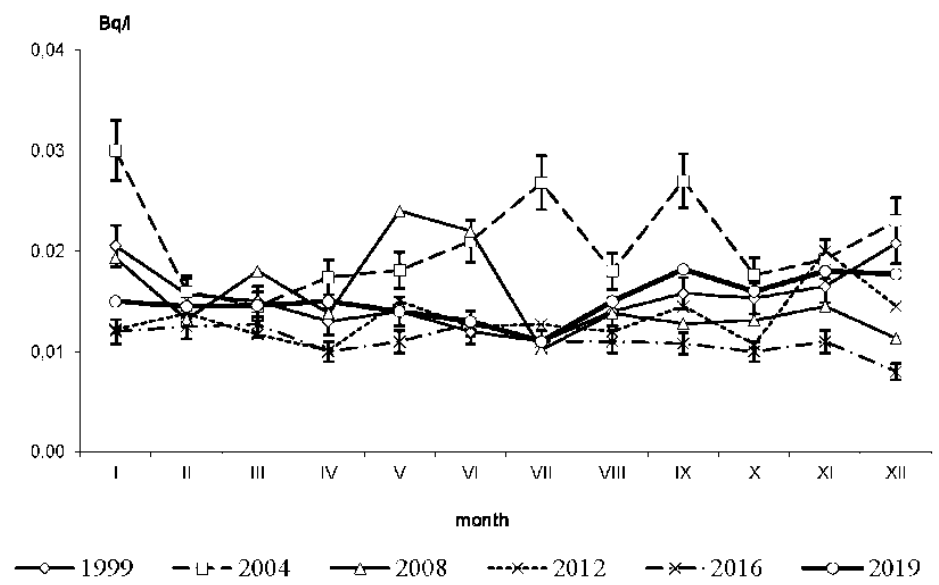

Fig. 8. Dynamics during the year of specific activity of ${ }^{137} \mathrm{Cs}$ in the water of the Southern Bug River in the area with. Buzke ( $7 \mathrm{~km}$ below the control line) (1999-2019)

This tendency is explained by the peculiarities of the hydrological conditions existing at this segment of the Southern Bug River. In the area of the checkpoint (point 4), the river bed is narrower, with many boulders in the river channel, because the river flows between high and places and steep banks. Due to such features, the flow velocity is increased, making the amount of silt and the mass of aquatic vegetation in this section of the river much smaller. This, in turn, greatly reduces the sorption-desorption process of ${ }^{137} \mathrm{Cs}$ through water components, from which the level of oscillation of radiocesium activity in river water is significantly reduced.

Figure 9 shows that radio cesium activity in the Southern Bug River (points 3-5) is closely related to the ${ }^{137} \mathrm{Cs}$ content of the SOU cooler rate. This is especially noticeable according to 1999, 2004. The low level of radiocesium activity in the cooler of the SPSP in 1999 caused the summation of all graphs to one point and, conversely, when in 2004 the activity of radiocesium in the cooler rate increased. the dynamics of ${ }^{137} \mathrm{Cs}$ specific activity at all observation points differed from one another, clearly indicating the effect of radiocesium from the cooler pond on its activity level in the Southern Bug River. 


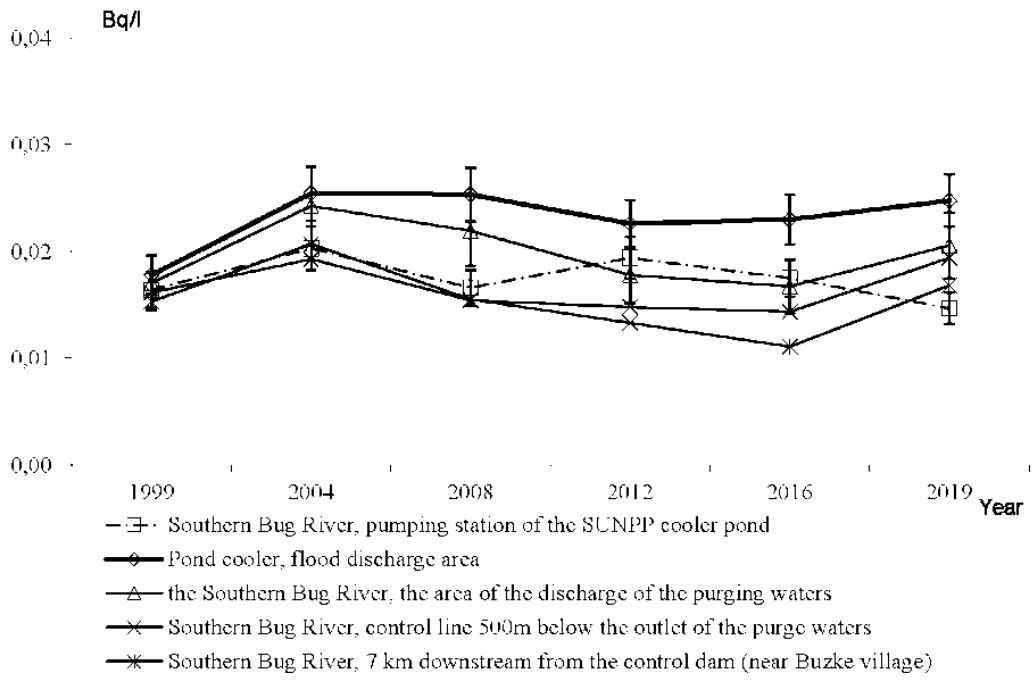

Fig. 9. Dynamics during the year of specific activity of ${ }^{137} \mathrm{Cs}$ in the water of the Southern Bug River and the cooler rate of the Southeast NPP (during 1999-2019)

Studies of the content of ${ }^{137} \mathrm{Cs}$ in biota and sediments in different parts of the Southern Bug have shown that there is a difference in the coefficients of accumulation of ${ }^{137} \mathrm{Cs}$ by algae in different parts of the river from Pervomaisk (850 Bq / kg / Bq / l) to Nikolaev (1200 Bq/kg / Bq/l) (Table 1).

Table 1

Average values of ${ }^{137} \mathrm{Cs}(\mathrm{KH})$ accumulation coefficients with algae and sediments at different sites of the aquatic ecosystem of the Southern Bug River. Bq/kg / Bq / I

\begin{tabular}{|c|c|c|}
\hline Place of observation & $\mathrm{KH}_{\text {the bottom one. }}$ & $\mathrm{KH}_{\text {algae }}$ \\
\hline near Pervomaisk & $1000 \pm 200$ & $850 \pm 150$ \\
\hline near the city of Nikolaev & $1875 \pm 230$ & $1200 \pm 170$ \\
\hline
\end{tabular}

Deposition of ${ }^{137} \mathrm{Cs}$ with sediments was also characterized by different accumulation factors (KN): from 1000-1 $200 \mathrm{~Bq} / \mathrm{kg} / \mathrm{Bq} / \mathrm{l}$ (near Pervomaisk) to $1875-1200 \mathrm{~Bq} / \mathrm{kg} / \mathrm{Bq} / \mathrm{l}$ (near Mykolayiv). The upper reaches of the river (from Migia village to Yuzhnoukrainsk) are characterized by a threshold that causes the deposition of radiocesium at the bottom, although by chemical parameters ( $\mathrm{pH} 4,5-5,0)$ the aqueous medium has the property of desorption of radiocesium from water components. 
On the river section with slower river flow and where, due to the removal of the purging waters of the NPP cooler, the water was characterized by higher rates of total mineralization (up to $1000 \mathrm{mg} / \mathrm{l}$ ) at $\mathrm{pH} 5,8-6,0$, with the highest $\mathrm{KH}^{137} \mathrm{Cs}$ algae and bottom sediments. A feature of the lower part of the river (from Kovalivka village to Mykolayiv city) is the presence of a constant river flow only during floods, as well as penetration into the river under the influence of wind surges of the estuary waters. This leads to increased mineralization of water (about $700-800 \mathrm{mg} / \mathrm{l}$ ), because of which the bottom of the river is covered with estuary deposits, and the $\mathrm{pH}$ of the medium is 6,5-7,0. Thus, due to the mixing of river and estuary waters in the lower reaches and high salts in the pond-cooler, this section of the slow-flow river creates favorable conditions for the formation of sedimentary forms of radiocesium and its concentration in the bottom sediments.

The calculated radioactivity factors of reservoirs along the Southern Bug River (Table 2) may be an indicator of the radiation status of these water bodies.

Table 2

\section{Radioactivity factors of ${ }^{137}$ Cs aquatic ecosystem} of the Southern Bug River

\begin{tabular}{|c|c|c|}
\hline Place of observation & $R_{\text {algae }}$ & $R_{\text {the bottom one. }}$ \\
\hline Southern Bug River near Pervomaisk & 0,89 & 0,73 \\
\hline Buga estuary near the city of Nikolaev & 0,94 & 0,81 \\
\hline
\end{tabular}

Note: $R_{\text {algae }}$ - radioactivity factor by biotic component (aquatic vegetation),

$R_{\text {the bottom one }}$ - bottom wave radioactivity factor.

Preliminary estimation of the radioactivity factors showed that due to different $\mathrm{KN}{ }^{137} \mathrm{Cs}$ aquatic vegetation, there is a difference in their values depending on the river section: 0,89 in the city of Pervomaisk, 0,94 in the Nikolaev district. Even more significant is the difference between ecosystem radioactivity factors, calculated without taking into account the biotic component, that is, for the winter period: 0,73 in the district of Pervomaisk and 0,81 in the district of Mykolaiv. This difference is easily explained by the change in the salt regime of the river and the decrease in the amount of biomass in winter, which is, as it is determined, the main regulator of the ecological status of the aquatic ecosystem.

However, for the Southern Bug ecosystem, fish is an important component of the biotic component that can theoretically affect the magnitudes of its radioactive factor. The results of the ${ }^{137} \mathrm{Cs} \mathrm{CN}$ assessment by fishery organisms downstream of the river indicated that in the flesh that prefers the surface environment, the $\mathrm{CN}$ in the pulp was $37 \mathrm{~Bq} / \mathrm{kg} / \mathrm{Bq} / \mathrm{l}$, in the interior $-101 \mathrm{~Bq} / \mathrm{kg} / \mathrm{Bq} / \mathrm{l}$; for the bream inhabiting the benthic environment, the CNs were 16 and $113 \mathrm{~Bq} / \mathrm{kg} / \mathrm{Bq} / \mathrm{l}$ in the pulp and viscera, respectively; for pike perch in the pulp was $136 \mathrm{~Bq} / \mathrm{kg} / \mathrm{Bq} / \mathrm{l}$, and in the 
interior - $58 \mathrm{~Bq} / \mathrm{kg} / \mathrm{Bq} / \mathrm{l}$. These values indicate the difference in the magnitudes of ${ }^{137} \mathrm{Cs}$ accumulation by fish organisms not only depending on the fish's way of life (peaceful, predatory), but also on its habitat in the freshwater ecosystem, the intensity of ${ }^{137} \mathrm{Cs}$ accumulation by algae, etc.

Taking these data into account for the estimation of the radio-capacity of the Southern Bug ecosystem, we have a preliminary estimate of the magnitude of the radioactivity factor of the biotic component of the river bottom - 0,96. In order to assess the impact on the magnitude of the radioactivity factor of the biotic constituent of the upper reaches of the river, it is necessary to continue radioecological studies of the fish organisms living in this river waters ${ }^{3}$.

Summing up, we believe that when calculating the flow of ${ }^{137} \mathrm{Cs}$ into the river and assessing the radiation situation, it is necessary to take into account the different indicators of radio intensity in its various sections. Given the biota functions in the functioning of the freshwater reservoir ecosystem and the high day-to-day accumulation coefficients of ${ }^{137} \mathrm{Cs}$, it can be argued that the presence of normally functioning microflora, as well as multicellular plants and animals, are necessary conditions for stable functioning, radioactivity, an indicator of regulation of discharges into the freshwater environment.

Knowing these biota functions in the freshwater reservoir of aquatic vegetation, macrophytes can be used to decontaminate the process reservoir. For this purpose, we have investigated the accumulation of radionuclides by the water vegetation of the cooler of the Southeastern Nuclear Power Plant. Studies have shown that in some parts of the reservoir there are small clusters of redfish (Potamogeton natans), duckweed, elodei and carob. During 6-7 months (April - November), active development of filamentous algae, mainly Cladophora fracta, was recorded.

A positive factor for breeding in the pond-cooler of the water vegetation was the sufficient presence in the reservoir of seeds, fruits, buds, as well as parts of roots and stems of aquatic plants coming from the Tashlyk beam and from the Southern Bug.

Although it is difficult to systematically quantify biomass reserves of aquatic plants, their volume of extinction and extinction, studies over three years have shown that active development of algae in the waters of the reservoir occurs in 5 sites: these are shallow bays, with a total area of $1,12 \mathrm{~km}^{2}$.

The first section is a shallow bay at the top of the reservoir, measuring $0,4 \mathrm{~km}^{2}$. Three more sites are located closer to the NPP. These are the bays on the eastern part of the coast, with an area of $0,35 \mathrm{~km}^{2}, 0,08 \mathrm{~km}^{2}$ and 0,05 $\mathrm{km}^{2}$ respectively. The fifth $0,24 \mathrm{~km}^{2}$ plot is located on the west coast, in the

\footnotetext{
${ }^{3}$ Григор'єва Л., Томілін Ю. Формування радіаційного навантаження на людину в умовах півдня України: чинники, прогнозування, контрзаходи. Миколаїв : Вид-во чДУ ім. Петра Могили, 2009.
} 
area of the old garden. All sites are located away from the main stream, shallow and are most adapted to the development of aquatic plants. According to the results of sampling of water plants from the experimental sites, the average estimated biomass of potest (Potamogeton natans) per square meter was $5 \mathrm{~kg}$, filamentous algae (Cladophora fracta) - about $2 \mathrm{~kg}$. The reddish biomass of the five sections of the cooler pond was 5,6 x $106 \mathrm{~kg}$ and the pantry was $2,24 \times 106 \mathrm{~kg}$. The results of the measurement of the specific activities of radionuclides in aquatic plants (Cladophora fracta and Potageton nataus) showed that, in addition to ${ }^{90} \mathrm{Sr},{ }^{137} \mathrm{Cs},{ }^{3} \mathrm{H}$, natural $\left({ }^{226} \mathrm{Ra}\right.$, thorium isotopes, uranium) and stationary radionuclides $\pm{ }^{24} \mathrm{Mn},{ }^{24} \mathrm{Mn}$ were also detected in samples $0 \mathrm{~Bq} / \mathrm{kg})-60 \mathrm{Co}(3,7 \pm 1,1 \mathrm{~Bq} / \mathrm{kg})$. The average content of ${ }^{90} \mathrm{Sr}$ in Cladophora fracta was $7,2 \pm 2,1 \mathrm{~Bq} / \mathrm{kg},{ }^{137} \mathrm{Cs}-$ $10,4 \pm 2,4 \mathrm{~Bq} / \mathrm{kg}$ and $32 \pm 10 \mathrm{~Bq} / \mathrm{kg}$, respectively. In the reds, the contents of $\mathrm{Sr}$, Cs and $\mathrm{H}$ were at levels: $16,9 \pm 3,5 \mathrm{~Bq} / \mathrm{kg}, 18,9 \pm 3,7 \mathrm{~Bq} / \mathrm{kg}$ and $32 \pm 10 \mathrm{~Bq} / \mathrm{kg}$, respectively. Relatively lower radiation-sorption quality was recorded in plants with low humidity.

Taking into account the calculated total determined biomass of aquatic plants in five sites and their specific radionuclide activity, the total radionuclide activity deposited by the above mentioned reddish biomass was calculated: $\mathrm{Sr}$ - about 9,5 $107 \mathrm{~Bq},{ }^{107} \mathrm{Cs}$ - about 9,5 $\cdot 107 \mathrm{~Bq}, 107 \mathrm{~Bq}$ and $\mathrm{H}$ are about $18,0 \cdot 107 \mathrm{~Bq}$, as well as the treasure chest: $\mathrm{Sr}-$ about 1,6 107 $\mathrm{Bq}$, and $\mathrm{Cs}-$ about $2,3 \cdot 107 \mathrm{~Bq}$.

Comparing these values with the average content of ${ }^{90} \mathrm{Sr},{ }^{137} \mathrm{Cs},{ }^{3} \mathrm{H}$ in the whole volume of water of the NPP cooler, it can be stated that they correlate well, that is, the biomass of the water plants of the five sites can be deduced in a relatively short time (for $2-3$ vegetative periods) from the reservoir a considerable amount of activity of the main dose-forming radionuclides $\left({ }^{90} \mathrm{Sr},{ }^{137} \mathrm{Cs},{ }^{3} \mathrm{H}\right)$.

\section{CONCLUSIONS}

1. The dynamics of the activity of radiocesium in the freshwater ecosystem, which includes the technological reservoir - pond cooler, is determined by the level of ${ }^{137} \mathrm{Cs}$ in this reservoir.

2. Radio intake factors of the freshwater ecosystem of the Southern Bug River at ${ }^{137}$ Cs above the location of the Southeastern Nuclear Power Plant is 0,89 , in the river mouth area $-0,94$. Taking into account the fish component, the radioactive factor of the biotic component of the Bug estuary is 0,96 . The calculated radioactive capacity factors of the reservoirs along the Southern Bug can serve as an indicator of the radiation status of the ecosystem of these water bodies.

3. The presence of normal-functioning microflora, as well as multicellular plants and animals, are prerequisites for the stable functioning of reservoirs as sinks of radionuclides that fall into them, and may serve as an indicator of the regulation of discharges into the freshwater environment. 
4. The biomass of the aquatic plants of the five sites can remove a considerable amount of the activity of the main dose-forming radionuclides $\left({ }^{90} \mathrm{Sr},{ }^{137} \mathrm{Cs},{ }^{3} \mathrm{H}\right)$ in a relatively short time $(2-3$ vegetative periods $)$.

\section{SUMMARY}

Materials of radioecological studies of the freshwater ecosystem, which includes the technological reservoirs of the NPP, are presented. Long-term studies on the behavior and accumulation of ${ }^{137} \mathrm{Cs}$ in water components of the Southern Bug River Basin and technological reservoirs (cooler ponds) of the South Ukrainian NPP are summarized. The radioactivity factors of the freshwater ecosystem of the Southern Bug River at ${ }^{137} \mathrm{Cs}$ were determined. It is shown that the calculated factors of the radio-capacity of the reservoirs along the Southern Bug can serve as an indicator of the radiation status of the ecosystem of these water bodies. It is shown that the presence of normally functioning microflora, as well as multicellular plants and animals are necessary conditions for stable functioning of reservoirs as radionuclide absorbers, and may be an indicator of regulation of discharges into the freshwater environment.

\section{REFERENCES}

1. Кутлахмедов Ю., Корогодін В., Кольтовер В. Основи радіоекології. Київ : Вища школа, 2003.

2. Радіоекологія. Камерні моделі / Ю. Кутлахмедов та ін. 2013.

3. Григор'єва Л., Томілін Ю. Формування радіаційного навантаження на людину в умовах півдня України: чинники, прогнозування, контрзаходи. Миколаїв : Вид-во ЧДУ ім. Петра Могили, 2009.

\section{Information about authors:} Grygorieva L. I., Doctor of Biological Sciences, Professor, Head of Ecology Department Petro Mohyla Black Sea National University 10, 68 Desantnykiv str., Mykolaiv, 54003, Ukraine

Makarova O. V.,

Senior Lecturer in the Department of Ecology

Petro Mohyla Black Sea National University 10, 68 Desantnykiv str., Mykolaiv, 54003, Ukraine 